\title{
FORTY YEARS OF WONDERING IN THE WILDERNESS AND NO CLOSER TO THE PROMISED LAND: BILSKI'S SUPERFICIAL TEXTUALISM AND THE MISSED OPPORTUNITY TO RETURN PATENT LAW TO ITS TECHNOLOGY MOORING
}

\begin{abstract}
Peter S. Menell*
This Article critically analyzes Bilski v. Kappos, the Supreme Court's first decision on patentable subject matter since the early 1980s. It shows how the majority's effort to shoehorn patentable subject matter into a superficial textualist mold obfuscates patentable subject matter boundaries and undermines the patent system on multiple levels. The Article contends that the patentable subject matter pathology cannot be cured without confronting the roots of the disease: the lack of a forthright, principled framework for delineating the boundaries of patentable subject matter. The solution lies in recognizing that patentable subject matter cannot evolve to meet the new challenges of the information age without integrating eighteenth-, nineteenth-, and twentieth-century sources of patentable subject matter law into a flexible and evolving body of common law that is sensitive to history, statutory evolution, constitutional constraints, and an understanding of modern science and technology. This will be particularly important as courts confront the patentability of DNA compounds, diagnostic tests, and unforeseeable information age innovations.
\end{abstract}

INTRODUCTION

I. THE ARC OF PATENTABLE SUBJeCt MATtER LIMITATIONS .......................1292

A. The Formative Period

B. Evolution of the Scope of Patentable Subject Matter to the Modern Era

1. "Art".....

2. Natural principles 1295

* Professor of Law, University of California at Berkeley School of Law, and Director, Berkeley Center for Law \& Technology. I thank Rob Merges, Michael Meurer, David Nimmer, Bertrall Ross, Claire Sylvia, and Joel Wallace for helpful discussions and comments along the journey to this Article. 
C. The Patent Act of 1952

D. The Early Modern Patentable Subject Matter Era..................................1297

E. 1981-2010: Wondering in the Patentable Subject Matter Wilderness .....1298

II. BILSKIV. KAPPOS AND THE TEXTUALIST TURN

A. Reducing Two Centuries of Patentable Subject Matter Jurisprudence to a Paragraph

B. (Mis) construing the Patent Act............................................................1301

1. The Patent Act of 1952 ...............................................................1302

2. The First Inventor Defense Act of 1999 ...........................................1303

C. Patentable Subject Matter Incoherence ………………........................1304

III. THE COSTS OF UNGROUNDED AND INCOHERENT PATENTABLE SUBJECT

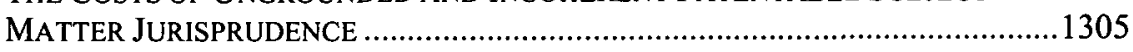

IV.INTEGRATING CONSTITUTIONAL LIMITATIONS, COMMON LAW

JURISPRUDENCE, AND STATUTORY INTERPRETATION IN DELINEATING THE

BOUNDARIES OF PATENTABLE SUBJECT MATTER..........................................1307

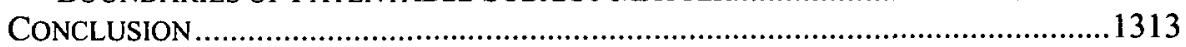

\section{INTRODUCTION}

When the Supreme Court granted certiorari in Bilski v. Kappos in the summer of 2009, ${ }^{\mathrm{l}}$ the patent community was galvanized. In view of the murky and conflicting reasoning of the Benson-Flook-Diehr trilogy ${ }^{2}$ from the 1970s and early 1980 s and the Supreme Court's inaction on patentable subject matter since that time, it appeared that the Court was poised to clarify one of the most confounding and potentially critical areas of patent law at a crucial juncture in the information age. Why else, in this era of parsimonious certiorari grants, ${ }^{3}$ would the Court review the Federal Circuit's rejection of a patent that nearly everyone considered unworthy of protection? The Federal Circuit's fractured en banc resolution of patentable subject matter in In re Bilski presented an opportunity for the Supreme Court to reengage and bring coherence to the boundaries of patentable subject matter. ... Or so many hoped.

Throughout industrial history, the advent of major new technological fields has produced controversy over the boundaries of patentable subject matter. The question of whether software-related inventions are patentable emerged forty years ago with the opening of a distinct marketplace for software products. Coming during the first decade of software's ascendancy, the Benson-FlookDiehr trilogy produced more heat than light in applying century-old patent juri-

1. See Bilski v. Doll, 129 S. Ct. 2735 (2009) (mem.).

2. See infra Part I.D.

3. Compare Peter L. Strauss, One Hundred Fifty Cases per Year: Some Implications of the Supreme Court's Limited Resources for Judicial Review of Agency Action, 87 ColUM. L. REv. 1093, 1100 (1987) (noting that the Court tended to hear about one hundred fifty cases per year in the mid- to late 1980s), with Paul D. Carrington \& Roger C. Cramton, Judicial Independence in Excess: Reviving the Judicial Duty of the Supreme Court, 94 CORNELL L. REv. 587, 630 (2009) (noting that the Court tended to hear about eighty cases per year in the mid- to late 2000s). 
sprudence to an amorphous, rapidly developing field of technology. Benson and Flook saw the exclusion of patents on abstract principles as a significant limitation on the patentability of computer software. Without overtly overruling those decisions, Diehr reversed course and opened the software patent floodgates. The Patent and Trademark Office (PTO), Federal Circuit, lower courts, and patent community have struggled mightily since that time to make sense of those decisions. ${ }^{4}$

Paralleling the software revolution, biotechnology has also emerged during the past several decades, raising other patentable subject matter controversies. The Supreme Court's Chakrabarty ${ }^{5}$ decision approved the patentability of nonnaturally occurring, genetically altered microorganisms, but the Court has yet to confront the patentability of human-isolated, naturally occurring DNA molecules ${ }^{6}$ and medical diagnostic tests.

The past forty years of patentable subject matter jurisprudence harkens back to the Israelites' wandering through the wilderness following the exodus from Egypt. ${ }^{7}$ But unlike Moses's leadership, which brought the Israelites to the Promised Land by year forty, the Supreme Court's Bilski decision has left the patent community in the wilderness. ${ }^{8}$

Such a disconcerting result was avoidable. Drawing upon historical sources explicating the constitutional and jurisprudential foundation of patentable subject matter, Justice Stevens's concurring opinion pointed the way out of the wilderness, at least with regard to business methods. The fractured five-vote majority instead retreated into a superficial textual wilderness. To some extent, the decision reflects the Roberts Court's tendency toward vague and narrow decisions. ${ }^{9}$ But it also reveals a fundamental failing of modern textualism-its inability to account for and integrate the common law jurisprudence explicating centuries-old statutory text.

Unfortunately, the problems posed by "business method" patents will continue to plague the information technology and financial industries. Moreover, the failure of the Bilski majority to elucidate the basis-constitutional, statutory, and/or jurisprudential-for deciphering the boundaries of patentable subject matter leaves other important industries and decisionmakers in the wilder-

4. See infra Part I.E.

5. Diamond v. Chakrabarty, 447 U.S. 303 (1980).

6. See, e.g., U.S. Patent No. 4,472,502 (filed Aug. 16, 1982) (claiming the Lactobacillus bacteria malolactic gene); U.S. Patent No. 4,680,264 col.16 1.16 (filed July 1, 1983) (using the term "isolated DNA").

7. See Numbers 14:33 ("And your children shall be wanderers in the wilderness forty years ....").

8. See, e.g., Michael L. Kiklis, Bilski v. Kappos: Back to 1981, COMPUTER \& INTERNET LAW., Oct. 2010, at 1, 1 ("With the Bilski decision, the Supreme Court has finally spoken again and sent us back to 1981." (footnote omitted)); Michael Risch, Forward to the Past, Cato SuP. CT. Rev. 333, 365 (2010).

9. See Adam Liptak, Justices Long on Words but Short on Guidance, N.Y. TIMES, Nov. 18, 2010, at Al. 
ness. ${ }^{10}$ What the patent community needed was a coherent manual for navigating the boundaries of patentable subject matter. What it got was noncommittal, hypertextual, incoherent rambling.

This Article critically analyzes the boundaries of patentable subject matter on the basis of the historical record and first principles of statutory construction. Part I traces the history of patentable subject matter jurisprudence. Part II examines the Bilski majority decision, showing how its effort to shoehorn patentable subject matter into a superficial textual mold obfuscates patentable subject matter boundaries. Part III explores the fallout from ungrounded and vague patentable subject matter jurisprudence. Part IV points the way toward a coherent, historically faithful, dynamic, and pragmatic framework for delineating the boundaries of patentable subject matter.

\section{The ARC OF PATENTABLe SubJect MATter Limitations}

At first blush, the boundaries of patentable subject matter appear straightforward. Section 101 of the Patent Act states that "[w]hoever invents or discovers any new and useful process, machine, manufacture, or composition of matter, or any new and useful improvement thereof, may obtain a patent therefor, subject to the conditions and requirements of this title." ${ }^{11}$ The text plainly encompasses any invention or discovery of processes, machines, manufactures, and compositions of matter, including previously unrecognized minerals, molecules, and natural laws. Yet the Supreme Court has long held that the Patent Act does not extend to "laws of nature, physical phenomena, and abstract ideas." ${ }^{\prime 2}$ Hence, fidelity to text and jurisprudence requires forthright explication of history, judicial philosophy, and legislative intent.

Since the critical language dates back over two hundred years and is intertwined with Congress's constitutional authority, we begin with the nation's formative period and then proceed through the evolution of patentable subject matter in the nineteenth and early twentieth centuries, the conditions leading to the Patent Act of 1952, the Supreme Court jurisprudence in the 1970s and early 1980 s, and the thirty-year hiatus leading up to Bilski.

\section{A. The Formative Period}

Congress's authority to enact patent protection flows from the power " $[\mathrm{t}] \mathrm{o}$ promote the Progress of . . . useful Arts, by securing for limited Times to ...

10. See Ass'n for Molecular Pathology v. U.S. Patent \& Trademark Office, 702 F. Supp. 2d 181 (S.D.N.Y. 2010) (invalidating patents on isolated naturally occurring DNA compounds and diagnostic tests based on those compounds).

11. 35 U.S.C. $\$ 101$ (2006).

12. E.g., Diamond v. Chakrabarty, 447 U.S. 303, 309 (1980). 
Inventors the exclusive Right to their . . . Discoveries." $" 13$ The constitutional text and original understanding of the Intellectual Property Clause demonstrate that protection for inventions was limited to the "useful Arts," while protection for writings could extend to all general knowledge, or "Science." " The first Congress entitled the initial patent act, "An Act to promote the progress of useful Arts." 15 After the initial act, Congress passed fourteen successive patent acts with titles directed to promoting "useful arts," "useful discoveries," or "useful inventions." 16 Thus, Congress's patent power was originally understood as limited to "useful Arts."17

Although the Framers did not expressly define the term "useful Arts," 18 usage at the time indicates that it related to trades utilizing what we would today call "technology." 19 Just days before the Constitutional Convention of 1787 , one delegate gave examples of the "useful arts":

Under all the disadvantages which have attended manufactures and the useful arts, it must afford the most comfortable reflection to every patriotic mind to observe their progress in the United States and particularly in Pennsylvania. ... Permit me however to mention them under their general heads: meal of all kinds, ships and boats, malt and distilled liquors, potash, gunpowder, cordage, loaf-sugar, pasteboard, cards and paper of every kind, books in various languages, snuff, tobacco, starch, cannon, musquets, anchors, nails, and very many other articles of iron, bricks, tiles, potters ware, mill-stones, and other stone work, cabinet work, trunks and Windsor chairs, [and] carriages and harness of all kinds... 20

13. U.S. CONST. art. $\mathrm{l}, \S 8$, cl. 8; see 1 ERNEST BAINBRIDGE LIPSCOMB III, LIPSCOMB'S WALKER ON PATENTS $\S 2: 1$ (3d ed. 1984) (discussing scholarship on the interpretation of the Intellectual Property Clause).

14. See The Federalist No. 43, at 271-72 (James Madison) (Clinton Rossiter ed., 1961) ("The copyright of authors has been solemnly adjudged in Great Britain to be a right of common law. The right to useful inventions seems with equal reason to belong to the inventors." (emphasis added)); see also 1 LIPSCOMB, supra note 13, \& 2:1, at $71-73$ (describing Pinckney's and Madison's likely roles in drafting the clause).

15. Act of Apr. 10, 1790, ch. 7, 1 Stat. 109, 109 (emphasis added).

16. See 1 LIPSCOMB, supra note $13, \S 2: 1$, at $83-84$.

17. See Graham v. John Deere Co., 383 U.S. 1, 5 (1966) (observing that the patent power is a "qualified authority . . [ [which] is limited to the promotion of advances in the "useful arts").

18. See Arthur H. Seidel, The Constitution and a Standard of Patentability, 48 J. PAT. OFF. SOC'Y 5, 10 (1966) ("No historical writings or events have been found analyzing the [Intellectual Property Clause] ....”).

19. See Paulik v. Rizkalla, 760 F.2d 1270, 1276 (Fed. Cir. 1985) (en banc) (noting that the patent right, "constitutionally derived, was for the national purpose of advancing the useful arts-the process today called technological innovation").

20. TENCH COXE, AN ADDRESS to AN ASSEMBLy OF THE FRIENDS OF AMERICAN MANUfACTURES 17-18 (Philadelphia, Aitken \& Sons 1787). 
Alexander Hamilton praised the patent system as a way of encouraging "[inventions] which relate to machinery" in the United States. ${ }^{21}$ These sources support the textual inference that "useful Arts" concerned craft, trade, and industrial activities.

Historians and patent scholars concur that the phrase "useful Arts," as used and understood circa 1787 , related to trades utilizing what we would today call "technology."22 The phrase "useful Arts" was understood in contradistinction to the eighteenth-century terms "polite," "liberal," and "fine" arts-which related to aesthetic and philosophical pursuits. ${ }^{23}$

\section{B. Evolution of the Scope of Patentable Subject Matter to the Modern Era}

The modern text delineating the scope of patentable subject matter was largely set by 1793: patents were available for "any new and useful art, machine, manufacture or composition of matter" and improvements thereof. ${ }^{24} \mathrm{Re}$ flecting the tenor of the era, courts would develop the contours of patentable subject matter in a common law tradition drawing upon English court decisions, treatises, and developing U.S. precedent. Two issues emerged: (1) the scope of "art," and (2) whether natural principles could be patented.

\section{1. "Art"}

The early treatise writers recognized that U.S. patent law extended to "art" so as to avoid the problem that English courts had in according protection to manufacturing processes under a statute directed to "new manufactures." 25 Thus, manufacturing and chemical processes were considered patentable arts. ${ }^{26}$

21. AleXANDER Hamilton, REPORT ON MANUfactures (1791), reprinted in THE REPORTS OF ALEXANDER HAMILTON 115, 175-76 (Jacob E. Cooke ed., 1964); see also THE FEDERALIST NO. 8, supra note 14, at 69 (Alexander Hamilton) (distinguishing between "the arts of industry, and the science of finance").

22. See, e.g., Robert I. Coulter, The Field of the Statutory Useful Arts, 34 J. PAT. OFF. SoC'Y 487, 496 (1952) ("It seems clear that 'useful arts' (as a unitary technical term) embraced the so-called industrial, mechanical and manual arts of the 18 th century ...."); Karl B. Lutz, Patents and Science: A Clarification of the Patent Clause of the U.S. Constitution, 32 J. PAT. OFF. SOC'Y 83, 87 (1950) (explaining that "useful arts" meant what we now call "technology," or "applied science"); Seidel, supra note 18, at 10 (suggesting that "useful Arts" in 1787 connoted useful or helpful trades).

23. See W. KeNRICK, AN ADDRESS to THE ARTISTS AND MANUFACTURERS OF GREAT BRITAN 21-38 (London, Domville 1774) (contrasting "useful arts" with "polite arts"); Coulter, supra note 22, at 494-96; John R. Thomas, The Patenting of the Liberal Professions, 40 B.C. L. REv. 1139, 1164 (1999).

24. Patent Act of 1793, ch. 11, 1 Stat. 318, 319-20.

25. See, e.g., George Ticknor CuRtis, A Treatise on the Law of Patents for USEFUL INVENTIONS 1-8 (Boston, Little, Brown \& Co. 3d ed. 1867).

26. See Tilghman v. Proctor, 102 U.S. 707, 729 (1881) (holding patentable a process of breaking down fat molecules into fatty acids and glycerine); Cochrane v. Deener, 94 U.S. 
The term "art," however, did not extend to all processes. George Ticknor Curtis, the leading early authority, ${ }^{27}$ observed that "invention" and "discovery" as used in the patent law were limited to "some new and useful effect or result in matter." 28 He defined "art" as used in the subject matter provision of the 1836 Act as "a new process or method of working or of producing an effect or result in matter." 29 All of his many illustrations, drawn from the case law, refer to improved manufacturing techniques involving physical objects. ${ }^{30}$

This understanding of "art" as applying to processes having physical effects continued throughout the nineteenth and twentieth centuries. William Robinson's 1890 treatise defined "art" as "an act or a series of acts performed by some physical agent upon some physical object, and producing in such object some change either of character or of condition. It is also called a 'process' ...."31 Robinson explained that "[a]n Art may be either a 'Force Applied,' a 'Mode of Application,' or the 'Specific Treatment of a Specific Object.", $32 \mathrm{He}$ noted further that "[a]n Art must Produce Physical Effects." ${ }^{.33}$ Given this understanding, the patent community more generally understood that patents concerned manufacturing methods, manufactures, machinery, and compositions of matter. Business methods and other nontechnological arts were considered beyond the scope of patentable subject matter well into the twentieth century. ${ }^{34}$

\section{Natural principles}

In Le Roy v. Tatham, ${ }^{35}$ the Supreme Court drew a distinction between natural forces, which cannot be patented, and the application of those forces, which can:

The word principle is used by elementary writers on patent subjects, and sometimes in adjudications of courts, with such a want of precision in its application, as to mislead. It is admitted, that a principle is not patentable. A principle, in the abstract, is a fundamental truth; an original cause; a motive;

780,788 (1877) ("A process is . . an act, or a series of acts, performed upon the subjectmatter to be transformed and reduced to a different state or thing."); CURTIS, supra note 25 , at 8-15.

27. See Robert Patrick Merges \& John Fitzgerald Duffy, Patent Law and POLICY 916 (3d ed. 2002).

28. CURTIS, supra note 25 , at xxiv.

29. Id. $\S 9$.

30. See id. $\S \S 9-19$.

31. 1 WILliam C. Robinson, THe LAw of PATENTS FOR USEFUl INVENTIONS $\S 159$ (Boston, Little, Brown \& Co. 1890) (quoting Cochrane, 94 U.S. at 788).

32. Id. $\S 165$.

33. See id. $\S 166$ ("Every invention, when applied according to the design of its inventor, must accomplish some change in the character or condition of material objects.").

34. See 1 R. CARL MOY, MOY's Walker ON PATENTS $\S$ 5:28 (4th ed. 2007) ("Until recently it had been considered well established that [business] methods were non-statutory.").

35. 55 U.S. (14 How.) 156 (1853). 
these cannot be patented, as no one can claim in either of them an exclusive right. Nor can an exclusive right exist to a new power, should one be discovered in addition to those already known. Through the agency of machinery a new steam power may be said to have been generated. But no one can appropriate this power exclusively to himself, under the patent laws. The same may be said of electricity, and of any other power in nature, which is alike open to all, and may be applied to useful purposes by the use of machinery.

In all such cases, the processes used to extract, modify, and concentrate natural agencies, constitute the invention. The elements of the power exist; the invention is not in discovering them, but in applying them to useful objects. Whether the machinery used be novel, or consist of a new combination of parts known, the right of the inventor is secured against all who use the same mechanical power, or one that shall be substantially the same.

A patent is not good for an effect, or the result of a certain process, as that would prohibit all other persons from making the same thing by any means whatsoever. This, by creating monopolies, would discourage arts and manufactures, against the avowed policy of the patent laws. ${ }^{36}$

This pragmatic, philosophical explication of the contours of patentable subject matter became the foundation for much patentable subject matter jurisprudence. A year later, the Supreme Court applied this framework in allowing Samuel F.B. Morse's claims to specific uses of electromagnetism in telegraphy, but rejecting a broad claim to "the use of the motive power of the electric or galvanic current, which I call electro-magnetism, however developed for marking or printing intelligible characters, signs, or letters, at any distances." 37

\section{The Patent Act of 1952}

Congress enacted the Patent Act of 1952 as part of a general effort to organize the U.S. Code and in response to a few specific proposals for changes in the prior law. ${ }^{38}$ With regard to patentable subject matter, the 1952 Act retained the 1793 Act's text virtually verbatim. The only pertinent difference between the 1793 and 1952 provisions is the substitution of the word "process" for "art." Substituting "process" for "art" was not intended to effect any substantive change or to supplant more than a century of jurisprudence interpreting "art." Rather, it was to avoid confusion with other uses of the word "art.",39

36. Id. at $174-75$.

37. O'Reilly v. Morse, 56 U.S. (15 How.) 62, 112 (1854).

38. See H.R. REP. No. 82-1923, at 5 (1952) ("[T]he principal purpose of the bill is the codification of title 35, United States Code and involves simplification and clarification of language and arrangement, and elimination of obsolete and redundant provisions . . . . The major changes or innovations in the title consist of incorporating a requirement for invention in $\$ 103$ and the judicial doctrine of contributory infringement in $\S 271 . ")$.

39. See id. at 6 ("'Art' in this place in the [prior] statute has a different meaning than the words 'useful art' in the Constitution, and a different meaning than the use of the word 'art' in other places in the statutes, and it is interpreted by the courts to be practically synonymous with process or method."). 
To clarify this substitution, Congress expressly defined "process" to mean "process, art or method, and includes a new use of a known process, machine, manufacture, composition of matter, or material." ${ }^{40}$ The House Report explained:

The definition of 'process' has been added in section 100 to make it clear that 'process or method' is meant, and also to clarify the present law as to the patentability of certain types of processes or methods as to which some insubstantial doubts have been expressed. 41

The "insubstantial doubts" referred to dicta in In re Thuau ${ }^{42}$ and some other decisions suggesting that a new use of a known machine, manufacture, or composition or matter could not be patented. ${ }^{43}$ Section 100 overruled that dicta.

Authoritative patent sources at the time recognized that the term " useful arts,' as used in the Constitution . . . is best represented in modern language by the word 'technology,",44 that laws of nature, scientific principles, and abstract ideas were unpatentable, ${ }^{45}$ and that business methods were unpatentable:

As instances of the non-patentability of ideas, mention may be made of the various systems for doing business, such as modes of bookkeeping, and hotel checking systems. It has been held that a "system" or method of transacting business is neither an "art," nor does it come within any other designation of patentable subject-matter, as for example, a system of cash-registering and checking for hotels apart from the physical means of conducting the system. ${ }^{46}$

\section{The Early Modern Patentable Subject Matter Era}

The scope of patentable subject matter reemerged on the Supreme Court's docket with the advent of computer software. The first case, Gottschalk v. Benson, ${ }^{47}$ involved an algorithm for converting binary-coded decimal numerals in-

40. Patent Act of 1952, ch. 950, $\S 100,66$ Stat. 792, 797 (codified as amended at 35 U.S.C. $\S 100(2006))$.

41. H.R. REP. No. 82-1923, at 6.

42. 135 F.2d 344, 347 (C.C.P.A. 1943).

43. See P.J. Federico, Commentary on the New Patent Act, 35 U.S.C.A. 1 (West 1954), reprinted in 75 J. PAT. \& TRADEMARK OFF. SOC'Y 161, 176-77 (1993).

44. Karl B. Lutz, Patents and Science: A Clarification of the Patent Clause of the U.S. Constitution, 18 GeO. WASH. L. REV. 50,54 (1949).

45. See, e.g., 1 ANTHONY William Deller, Walker on Patents $§ 18$ (1937).

46. Id. $\S 22$ (citing numerous cases); see Giles S. Rich, Principles of Patentability, 28 GEO. WASH. L. REV. 393, 393-94 (1960) ("Of course, not every kind of an invention can be patented. Invaluable though it may be to individuals, the public, and national defense, the invention of a more effective organization of the materials in, and the techniques of teaching a course in physics, chemistry, or Russian is not a patentable invention because it is outside of the enumerated categories of 'process, machine, manufacture, or composition of matter, or any new and useful improvement thereof.' Also outside that group is one of the greatest inventions of our times, the diaper service."). The unpatentability of business methods was also well settled within the Patent Office and courts as early as 1869. See Ex parte Abraham, 1869 Dec. Comm'r Pat. 59.

47. 409 U.S. 63 (1972). 
to pure binary numerals. In upholding the PTO's rejection of the patent on subject matter grounds, a unanimous Court, drawing upon Le Roy, Morse, and their progeny, articulated three principles for determining whether a process is patentable: (1) "Phenomena of nature, though just discovered, mental processes, and abstract intellectual concepts are not patentable, as they are the basic tools of scientific and technological work."48 (2) "Transformation and reduction of an article 'to a different state or thing' is the clue to the patentability of a process claim that does not include particular machines. ${ }^{, 49}$ And (3) algorithms may not be patented so as to avoid the practical effect of "wholly pre-empt[ing a] mathematical formula."

Six years later, the Supreme Court addressed whether a procedure for updating an alarm limit-measuring the present value of a process variable (e.g., the temperature), using an algorithm to calculate an updated alarm-limit value, and adjusting the updated value-was eligible for patent protection in Parker $v$. Flook. ${ }^{51}$ Justice Stevens upheld the PTO's rejection of the claim on the grounds that, since algorithms are unpatentable, merely integrating them into a process that involves postsolution activity cannot bring the resulting process within the scope of patentable subject matter: the process is unpatentable "not because it contains a mathematical algorithm as one component, but because once that algorithm is assumed to be within the prior art, the application, considered as a whole, contains no patentable invention." 52

Three years later, the Supreme Court largely reversed direction on the patentability of computer software in Diamond $v$. Diehr. ${ }^{53}$ Writing for a sharply divided Court, Justice Rehnquist effectively overrode Flook's statutory subject matter test in holding that even if a mathematical formula embedded within a process is unpatentable, the overall process - taken as a whole and resulting in physical and chemical transformation-falls within the scope of patentable subject matter. $^{54}$

\section{E. 1981-2010: Wondering in the Patentable Subject Matter Wilderness}

Following Diehr, the Supreme Court took a hiatus from addressing patentable subject matter. The Federal Circuit, formed shortly after the Diehr decision, gradually relaxed the standards for patentable subject matter. ${ }^{55}$ Patenting of computer software became routine and the PTO eventually developed guide-

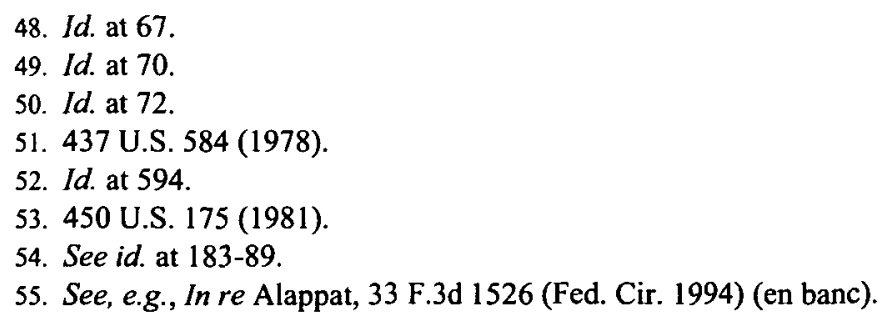


lines permitting software patents that did not wholly preempt use of an algorithm. $^{56}$

With the expansion of patentability of software-related inventions and the rise of digital commerce and the Internet, companies increasingly sought to patent computer-implemented business methods. In 1998, the Federal Circuit jettisoned the long-standing doctrine excluding business methods from patentability ${ }^{57}$ generating outrage in the financial community and calls for Congress to intercede. ${ }^{58}$ Congress enacted the First Inventor Defense Act of 1999 to limit the exposure of the financial community to the State Street decision. To speed passage of legislation insulating financial institutions from this controversial decision, Congress sidestepped $\S 101$ entirely and instead created a safe harbor from infringement suits for prior users of now-patentable business methods in $\S 273$ in Part III of Title 35, which addresses enforcement rights. ${ }^{59}$

\section{BILSKI $V$. KAPPOS AND THE TEXTUALIST TURN}

Bilski addressed whether a particular method for hedging energy-market risk was eligible for patent protection. Writing for the slim and fractured majority, ${ }^{60}$ Justice Kennedy approached the case through a textualist lens. ${ }^{61} \mathrm{He}$ skipped over the constitutional question-whether business methods categorically fall outside the legislative power " $[\mathrm{t}]$ o promote the Progress of . . u useful Arts." $"$ He focused on whether the Federal Circuit's "machine-or-trans-

56. See Examination Guidelines for Computer-Related Inventions, 61 Fed. Reg. 7478 (Feb. 28, 1996). 1998).

57. See State St. Bank \& Trust Co. v. Signature Fin. Grp., 149 F.3d 1368 (Fed. Cir.

58. See, e.g., Robert M. Kunstadt, Opening Pandora's Box, ReCORDER, Jan. 1999, at 20,20 (warning that "a firestorm of litigation threatens to engulf corporate America" and predicting "large-scale disruption of U.S. commerce, as sharp operators move to patent business methods and assert patents against the unsuspecting"); Jaret Seiberg, Ruling Threatens Banks with Patent Lawsuits, AM. BANKer, Sept. 2, 1998, at 3, 3 (asserting that the State Street decision "threatens to embroil the financial services industry in hundreds of patent infringement lawsuits," creating possible liability exceeding $\$ 2$ billion).

59. See H.R. REP. No. 82-1923, at 5 (1952) (explaining that Congress divided Title 35 into three distinct parts: I. Patent Office, II. Patentability of Inventions and Grant of Patents, and III. Patents and Protection of Patent Rights).

60. Justice Scalia declined to join two sections of the majority opinion. See Bilski v. Kappos, 130 S. Ct. 3218, 3223 (2010).

61. See id. at 3226 ("This Court has not indicated that the existence of these wellestablished exceptions gives the Judiciary carte blanche to impose other limitations that are inconsistent with the text and the statute's purpose and design."); id. at 3229 (plurality opinion) (noting that limitations on patentable subject matter must be "consistent with the statutory text"); id. at 3231 (majority opinion) ("[T] he Court once again declines to impose limitations on the Patent Act that are inconsistent with the Act's text."); id. ("[W]e by no means foreclose the Federal Circuit's development of other limiting criteria that further the purposes of the Patent Act and are not inconsistent with its text.").

62. U.S. ConST. art. I, § 8, cl. 8 (emphasis added). 
formation" test-“"[a] claimed process is ... patent-eligible under $\S 101$ if: (1) it is tied to a particular machine or apparatus, or (2) it transforms a particular article into a different state or thing"63 - comports with the statutory text and Supreme Court precedent. The majority opinion concluded that the Federal Circuit's "machine-or-transformation test," while a "useful and important clue ... for determining whether some claimed inventions are processes under $\S 101$," is "not the sole test for deciding whether an invention is a patenteligible 'process." ${ }^{.64}$ Without articulating the full battery of clues or tests, the majority nonetheless affirmed the Federal Circuit's judgment that Bilski's claimed invention was an unpatentable abstract idea.

In its effort to shoehorn analysis of patentable subject matter into a textualist mold, the Court collapsed the rich historical development of patentable subject matter doctrine into three amorphous, static, and ill-defined exceptions. The resulting methodology and analysis are incoherent.

\section{A. Reducing Two Centuries of Patentable Subject Matter Jurisprudence to a Paragraph}

Although the Patent Act does not expressly exclude any specific areas from patentability, Justice Kennedy had to grapple with substantial Supreme Court precedent holding that patent protection does not extend to "laws of nature, physical phenomena, and abstract ideas. ${ }^{105}$ He boiled that jurisprudence down to a single paragraph:

While these exceptions are not required by the statutory text, they are consistent with the notion that a patentable process must be "new and useful." And, in any case, these exceptions have defined the reach of the statute as a matter of statutory stare decisis going back 150 years. See Le Roy v. Tatham, 14 How. 156, 174-175 (1853). The concepts covered by these exceptions are "part of the storehouse of knowledge of all men ... free to all men and reserved exclusively to none." Funk Brothers Seed Co. v. Kalo Inoculant Co., 333 U.S. 127, 130 (1948).

These three sentences blithely sweep the fundamental interpretive problem of patentable subject matter - what grounds and guides the contours of the exclusions-under the rug.

Reflecting the majority's textualist leaning, the first sentence suggests that the exclusion of "laws of nature, physical phenomena, and abstract ideas" from the scope of patentable subject matter might be textually grounded - not in the subject matter categories but in the novelty and utility requirements. This is a dubious proposition historically ${ }^{67}$ and analytically. Benson's algorithm for
63. In re Bilski, 545 F.3d 943, 954 (Fed. Cir. 2008) (en banc).
64. Bilski, $130 \mathrm{~S}$. Ct. at 3227.
65. Id. at 3225 (quoting Diamond v. Chakrabarty, 447 U.S. 303, 309 (1980)).
66. Id. at 3225 (omission in original) (parallel citations omitted).
67. See supra Part I.A. 
converting from binary to binary-coded decimal satisfied the novelty requirement: his discovery had not been publicly known or used in the United States, nor patented or described in a printed publication anywhere in the world, prior to his patent. ${ }^{68}$ Furthermore, his method provided specific, substantial, and credible benefits to society. ${ }^{69}$

Justice Kennedy then invokes Le Roy v. Tatham to ground the exclusion of "laws of nature, physical phenomena, and abstract ideas" from "the reach of the statute as a matter of statutory stare decisis going back 150 years." But this invocation merely begs the question. It reveals nothing of the basis for delineating these exceptions. The Le Roy opinion, like most nineteenth- and twentiethcentury patentable subject matter decisions, does not expressly tie its analysis to specific statutory or constitutional text, but rather reasons loosely from various cases and treatise authorities as well as functional and policy considerations. It reflects the interpretive philosophy of an era in which Congress legislated tersely, recognizing that courts would evolve statutes through interpretation based on the underlying purposes. ${ }^{70}$ Yet the Bilski majority provides no guidance on how to interpret precedent constraining the scope of patentable subject matter.

The Bilski majority's third basis for excluding "laws of nature, physical phenomena, and abstract ideas" is equally opaque, invoking the Funk Bros. assertion that natural phenomena are "part of the storehouse of knowledge of all men ... free to all men and reserved exclusively to none." This statement, however, is internally inconsistent-how can something be in the "storehouse of knowledge" before it is known? Since the patent system seeks to promote the discovery of knowledge, which categories of knowledge should be unpatentable (and hence free to all) depends upon the premises for making deductions. The purpose of the patent law is to promote the search for such knowledge. The Funk Bros. decision fails to explain whether the exclusion of "phenomena of nature" derives from statutory, constitutional, or jurisprudential authority. It merely cites Le Roy (and later cases), which, as noted above, follows an informal interpretive tradition. Thus, the Bilski majority offers little guidance on how to decipher the limits on patentable subject matter.

\section{B. (Mis)construing the Patent Act}

The Bilski majority next rejected the Federal Circuit's machine-ortransformation test for patent eligibility of processes as inconsistent with textualist guideposts: (1) "courts should not read into the patent laws limitations

68. See 35 U.S.C. § 102(a) (2006).

69. See Brenner v. Manson, 383 U.S. 519, 534 (1966).

70. See infra Part IV. 
and conditions which the legislature has not expressed"; 71 and (2) "[i]n patent law, as in all statutory construction, ' $[\mathrm{u}]$ nless otherwise defined, words will be interpreted as taking their ordinary, contemporary, common meaning." "72 This textualist approach badly misconstrues the 1952 Act and thereby undermines the stability and grounded evolution of patentable subject matter. Its selective, result-oriented reading of the First Inventor Defense Act of 1999 reinforces more general concerns about textualism.

\section{The Patent Act of 1952}

The Bilski majority treats the language in $\S 101$ as though it were enacted in $1952 .{ }^{73}$ Yet nearly every word of $\S 101$ traces back to 1790 and 1793 . Congress did not intend to supplant more than a century of jurisprudence with the "ordinary, contemporary, common meaning" of the word "process."74 Rather, it intended to perpetuate the existing contours of patentable subject matter as expressed in the statute and recognized in patent jurisprudence. The substitution of "process" for "art" was for linguistic clarity-to avoid confusion with the constitutional phrase "useful Arts" and the concept of "prior art"-and not substantive reasons. ${ }^{75}$ Thus, to interpret the scope of patentable subject matter under the 1952 Act, the Court needed to delve into the contemporary specialized understanding of "process" that would have been available to members of the legislative body at the time of enactment. Those sources uniformly considered "process" to have a specialized meaning and business methods to be outside of the scope of patentable subject matter. ${ }^{76}$

By failing to examine the context surrounding the $1952 \mathrm{Act}^{77}$ the Bilski majority overlooked the long-standing interpretive canon presuming that codification statutes do not alter prior law. ${ }^{78}$ Congress clearly understood the terms

71. Bilski, 130 S. Ct. at 3226 (quoting Diamond v. Diehr, 450 U.S. 175, 182 (1981)) (internal quotation marks omitted).

72. Id. (second alteration in original) (quoting Diehr, 450 U.S. at 182) (some internal quotation marks omitted).

73. See id. at 3225 .

74. See Diehr, 450 U.S. at 184 ("Analysis of the eligibility of a claim of patent protection for a 'process' did not change with the addition of that term to $\S 101$. .).

75. See supra Part I.C.

76. See supra Part I.C.

77. See supra Part I.C.

78. See Finley v. United States, 490 U.S. 545, 554 (1989) ("Under established canons of statutory construction, "it will not be inferred that Congress, in revising and consolidating the laws, intended to change their effect unless such intention is clearly expressed." (emphasis added) (quoting Anderson v. Pac. Coast S.S. Co., 225 U.S. 187, 199 (1912))), superseded by statute, Civil Justice Reform Act of 1990, Pub. L. No. 101-650, 104 Stat. 5089. 
"art" and "process" to have special meanings, not the broadest meaning contained in Webster's 1954 edition. $^{79}$

\section{The First Inventor Defense Act of 1999}

After supplanting two centuries of jurisprudence interpreting the scope of patentable subject matter with a selected, result-oriented dictionary definition, the majority opinion deployed a second superficial textual reading. As noted above, Congress enacted the First Inventor Defense Act of 1999 as a stopgap measure to limit the exposure of the financial community to the State Street decision. ${ }^{80}$ Yet the majority read the creation of a safe harbor as tacit recognition that $\S 101$ encompasses business methods: "A conclusion that business methods are not patentable in any circumstances would render $\S 273$ meaningless. This would violate the canon against interpreting any statutory provision in a manner that would render another provision superfluous." ${ }^{\prime 81}$

Careful textualism rebuts this analysis. The 1999 legislation does not amend $\S 101$, which governs the scope of patentable subject matter. Arguments that the 1999 amendment overturned the established definition of "process," in essence, require that the amendment repealed the limited scope of $\S 101$ of the 1952 Act by implication. Such interpretations violate the "cardinal rule ... that repeals by implication are not favored." ${ }^{, 82}$ If the adoption of $\S 273$ expanded the scope of $\S 101$, it did so without Congress expressly acknowledging that effect, and thus would require the Court to endorse an implied repeal of the settled interpretation of $\S 101$ from the 1952 Patent Act.

The placement of the First Inventor Defense Act in Part III of Title 35 instead of Part II shows Congress's intent not to change the law governing "the conditions under which a patent may be obtained." ${ }^{, 83}$ Interpreting $\S 273$ as a revision to "the conditions under which a patent may be obtained" contradicts the Patent Act's structure. In defining "method" for purposes of the prior user defense, Congress avoided altering the definitions governing patentable subject matter in $\S 100{ }^{84}$ Instead, Congress included a definition of "method" in

79. See Bilski v. Kappos, 130 S. Ct. 3218, 3228 (2010) (referring to WEBSTER's NEW INTERNATIONAL DiCTIONARY 1548 (2d ed. 1954), which defines "method" as "[a]n orderly procedure or process ... regular way or manner of doing anything; hence, a set form of procedure adopted in investigation or instruction").

80. See supra Part I.E.

81. Bilski, 130 S. Ct. at 3228.

82. Morton v. Mancari, 417 U.S. 535, 549 (1974) (omission in original) (quoting Posadas v. Nat'l City Bank, 296 U.S. 497, 503 (1936)); see also Branch v. Smith, 538 U.S. 254, 273 (2003); Whitman v. Am. Trucking Ass'ns, 531 U.S. 457, 468 (2001) (noting that Congress "does not alter the fundamental details of a regulatory scheme in vague terms or ancillary provisions - it does not, one might say, hide elephants in mouseholes").

83. H.R. REP. 82-1923, at 5 (1952). title").

84. See 35 U.S.C. $\S 100$ (2006) (providing definitions of terms " $[w]$ hen used in this 
$\S 273$ (a) "[f]or purposes of this section," which deals only with the limited defense. ${ }^{85}$ Had Congress intended to endorse the State Street definition of "method," it could easily have applied that definition to the entire title, including $\S 101$.

\section{Patentable Subject Matter Incoherence}

The Supreme Court's methodology and analysis for determining whether a process falls within the scope of patentable subject matter could hardly be more opaque. By holding that the ordinary meaning of "process" does not support a requirement that the process be tied to a machine or transform an article into a different state or thing, ${ }^{86}$ the Supreme Court ruled that the machine-ortransformation test-while "a useful and important clue, an investigative tool"-is not the "sole test." 87 The Court indicated that this valuable tool is both under- and overinclusive.

The majority's basis for invalidating the Bilski patent reinforces the confusion. The Court concluded that allowing a patent on hedging "would effectively grant a monopoly over an abstract idea" because it "would pre-empt use of this approach in all fields." ${ }^{\prime 88}$ On this basis, the Court rejected all of Bilski's claims, some of which provided specific energy-hedging strategies, because "Flook established that limiting an abstract idea to one field of use or adding token postsolution components did not make the concept patentable. ${ }^{.89}$ The Court provided no effective guidance on how to distinguish between general ideas and the processes that implement them.

The Bilski plurality's ruminations reinforce the incoherence of the decision. Justice Kennedy noted:

The machine-or-transformation test may well provide a sufficient basis for evaluating processes similar to those in the Industrial Age--for example, inventions grounded in a physical or other tangible form. But there are reasons to doubt whether the test should be the sole criterion for determining the patentability of inventions in the Information Age. . . [T] [Te machine-or-transformation test would create uncertainty as to the patentability of software, advanced diagnostic medicine techniques, and inventions based on linear programming, data compression, and the manipulation of digital signals. ${ }^{90}$

The Court then rejected the Bilski patent on precisely the Industrial Age grounds-that it merely seeks to protect "an unpatentable abstract idea, just like the algorithms at issue in Benson and Flook." ${ }^{.91}$ But if the information age re-

85. Id. § 273(a) (emphasis added).

86. See Bilski, $130 \mathrm{~S}$. Ct. at 3226.

87. Id. at 3227.

88. Id. at 3231 .

89. Id.

90. Id. at 3227 (plurality opinion)

91. Id. at 3231 (majority opinion). 
quires new thinking, then why didn't the Court reassess the wisdom of a categorical rule against the patenting of algorithms - the quintessential information age invention?

The only definitive ruling in the case is that the Patent Act does not categorically exclude business methods. Since the machine-or-transformation test is "a useful and important clue," we can expect patent prosecutors to tie any business method patent to a general-purpose machine and include machine claims so as to "hedge" their $\S 101$ risk. The PTO, competitors, and courts will be left to deal with the fallout from the absence of effective guidance.

\section{The COSTS OF UnGrounded AND INCOHERENT PATENTABLE SUBJECT MATTER JURISPRUDENCE}

The Supreme Court's failure to articulate a clear roadmap for navigating the boundaries of patentable subject matter undermines the patent system on multiple levels. The principal goal of the patent system is to encourage potential inventors and investors to dedicate their labors and resources to inventive activities. Legal uncertainty about what can and cannot be protected, however, adds to the risk that must be factored into evaluating inventor and investor choices, which directly affects the quantity and direction of investment and creativity. It can discourage investments in new areas that rely upon substantial up-front financial investment. It can also fuel investments into claiming intellectual property in areas that are better cordoned off from patent protection.

On an administrative level, unprincipled and vague patentability standards undermine the functioning of patent institutions. The ability of the PTO and the federal courts to administer the patent system depends upon the scale of activity. The Bilski decision will fuel continuing efforts to obtain patents in the nontechnological as well as litigation over whether such "inventions" are patent eligible.

A more fundamental cost of incoherent patentability standards relates to the political economy of intellectual property rights. ${ }^{92}$ When the patentability of computer software, DNA compounds, and business methods first arose, industry players had not yet invested heavily in particular development paths, enabling open-minded debate within the industries and government. The lack of clear guidance, however, encouraged speculators to pursue patent protection, which in turn led industry players to believe that they ran a competitive risk by not pursuing a patent-acquisition strategy. ${ }^{93}$ As those investments increased,

92. See generally Peter S. Menell, The Challenges of Reforming Intellectual Property Protection for Computer Software, 94 COLUM. L. REV. 2644, 2651-54 (1994) (examining the political economy of software protection).

93. See, e.g., Mark Walsh, Bowing to Reality, Software Maker Begins Building a Patent Portfolio, RECORDER (San Francisco), Aug. 17, 1995, at 1 ("[W]hile [Oracle Corp., a leading relational database company] says it still [opposes software patents], it has ... embarked on an aggressive program to secure patents for its software products- 
industry players had more to lose from court decisions erasing those investments (even if the industry's innovative trajectory was brighter without patents)..$^{94}$

Once companies owned patents, they also came to see offensive opportunities. ${ }^{95}$ More reflective perspectives within industry gradually gave way to strident advocacy and lobbying strategies. ${ }^{96}$ Furthermore, as the companies expanded their patent departments, patent lawyers came to dominate internal corporate, industry, and trade-group policy positions, bringing their patentcentric viewpoint. The information needed to assess the efficacy of patent protection for the new field, much of which came from industry, became less objective as the tide shifted toward building and protecting patent portfolios. The simplistic slogan - "more patents equals more innovation"-crowded out more balanced assessments. The industries shifted their reform efforts toward limiting exposure to outsiders, such as nonpracticing entities in the information technology fields.

This dynamic fed back into the executive, legislative, and judicial arenas. The PTO, which previously opposed patenting of computer software, ${ }^{97}$ became more reactive in addressing patentable subject matter. ${ }^{98}$ As software patenting took hold, momentum built within the patent bar and some industry sectors for expansive protection. Given the many impediments to enacting legislation, Congress has taken the path of least resistance and awaited resolution of patentability limits by the Supreme Court. The vagueness of patentability standards and delay in addressing subject matter questions encouraged investment-backed expectations, which courts were disinclined to upset, thereby reinforcing the expansive tendencies. Moreover, public choice theory and empirical evidence suggest that the Federal Circuit, as a court specializing in patent adjudication, would be pro-patentee and inclined toward expanding the scope of patentable

primarily to protect itself against potential infringement claims, in the face of a sharp increase in recent years in the number of software patents issued by the PTO.”).

94. See Menell, supra note 92, at 2652.

95. See, e.g., Tom Krazit, Oracle Sues Google over Android and Java, CNET NEWS (Aug. 12, 2010), http://news.cnet.com/8301-30684_3-20013546-265.html.

96. See Diamond v. Diehr, 450 U.S. 175, 217 (1981) (Stevens, J., dissenting) (observing that in Benson, Flook, and Diehr, "the spokesmen for the organized patent bar have uniformly favored patentability and industry representatives have taken positions properly motivated by their economic self-interest," and that, "[n]otwithstanding fervent argument that patent protection is essential for the growth of the software industry, commentators have noted that 'this industry is growing by leaps and bounds without it"' (footnote omitted) (citation omitted)).

97. See id. at 218 (noting PTO opposition to software patents on policy, administration, and legal grounds); President's COMM'N ON THE PATENT SYS., "TO PROMOTE THE PROGRESS OF ... USEFUL ARTS" 13 (1966) (recommending against patent protection for computer software).

98. See MERGes \& DufFY, supra note 27, at 151 (noting that the PTO stopped petitioning for certiorari when its patentable subject matter rejections were overturned by the Court of Customs and Patent Appeals and Federal Circuit). 
subject matter. ${ }^{99}$ As a result, in each of the principal areas of controversysoftware, business methods, and DNA compounds - the debate over patent policy shifted from substantial skepticism about patentability to patent proliferation before Congress or the Supreme Court weighed in.

Thus, the lack of a clear roadmap for determining the boundaries of patentability, the Supreme Court's reluctance to weigh in on these questions in a timely manner, the Federal Circuit's inclination toward expansive patentable subject matter, the incoherence and vagueness of the Supreme Court's opinions, and the constitutional and political impediments to legislative action on patent reform have inclined the system reflexively toward expansive patentable subject matter whether or not it comports with good policy or constitutional, jurisprudential, and statutory limits.

\section{INTEGRATING CONSTITUTIONAL LIMITATIONS, COMMON LAW JURISPRUDENCE, AND STATUTORY INTERPRETATION IN DELINEATING THE BOUNDARIES OF PATENTABLE SUBJECT MATTER}

The current incoherence of patentable subject matter jurisprudence reflects the confluence of two powerful independent forces. The opening of vast new technological fields-as has occurred in digital technology and biotechnology-presents unprecedented challenges to jurists trying to apply amorphous bars against the patenting of laws of nature, physical phenomena, and abstract ideas. Since the founding of our nation, courts have evolved these doctrines within a hybrid constitutional/common law tradition. The continued vitality of this approach has come into conflict with the Supreme Court's textualist turn. ${ }^{100}$ Whether or not this "interpretive-regime change"101 appropriately addresses the challenges of interpreting modern legislation, ${ }^{102}$ it is poorly attuned to the challenges of interpreting text that has undergone two centuries of jurisprudential evolution.

As a result of these forces, the Bilski majority steered patentable subject matter into an incoherent, rigid, and static textualist mold at a time of rapid technological advance. Strict textualists might object that blame is being placed on the wrong branch of government, that Congress has primary authority over the patent laws and is free to steer its own course. But as the vagueness of the Bilski decision reveals, Congress can have little idea where its legislative authority lies. By failing to explicate the framework for delineating the scope of patentable subject matter or its contours, the Court shirked its larger constitu-

99. See William M. Landes \& Richard A. Posner, The Economic Structure of INTELLECTUAL PROPERTY LAW 334-53 (2003). (2010).

100. See John F. Manning, Second-Generation Textualism, 98 CALIF. L. REV. 1287

101. Philip P. Frickey, Interpretive-Regime Change, 38 LoY. L.A. L. REv. 1971 (2005).

102. See Jonathan T. Molot, The Rise and Fall of Textualism, 106 CoLUM. L. REV. 1 (2006) 
tional responsibility, thereby contributing to a pathological political dynamic that undermines the patent system. ${ }^{103}$

The proper interpretive path for patentable subject matter-from constitutional, jurisprudential, and pragmatic standpoints-requires courts to integrate the constitutional and jurisprudential traditions surrounding patentable subject matter with statutory construction principles and forthright recognition of the challenges of applying historic doctrines to unforeseeable technological developments. ${ }^{104}$ This can be done only by understanding the historical context for the various provisions and doctrines of patent law. ${ }^{105}$

Throughout the nineteenth century and first half of the twentieth century, courts fleshed out the skeletal, inchoate early patent statutes ${ }^{106}$ by filling in statutory gaps, integrating constitutional limitations on legislative power, and drawing upon tort principles to effectuate the enforcement of patent rights. ${ }^{107}$ Reflecting the jurisprudential style of those eras and the influence of their

103. See supra Part III.

104. See Jonathan R. Siegel, Nä̈ve Textualism in Patent Law, 76 BrooK. L. REV. (forthcoming 2011); cf. T. Alexander Aleinikoff, Updating Statutory Interpretation, 87 MICH. L. REV. 20, 22 (1988) (contrasting "archeological" and "nautical" approaches to interpretation); William N. Eskridge, Jr., Overruling Statutory Precedents, 76 GEO. L.J. 1361, 1392 (1988) ("[A]ren't most statutes common law statutes, to the extent that they have gaps and ambiguities which Congress fully expects the judiciary to fill?"); Peter L. Strauss, On Resegregating the Worlds of Statute and Common Law, 1994 SUP. CT. REV. 429, 436 (discussing "the issue of integrating statutory and other law").

105. Judge Frank Easterbrook, among the intellectual founders of textualism, recognizes that some "common law statutes" permit evolution of meaning as applied over time. See Frank H. Easterbrook, Statutes' Domains, 50 U. CHI. L. REv. 533, 544 (1983) ("The statute books are full of laws, of which the Sherman Act is a good example, that effectively authorize courts to create new lines of common law."). The antitrust laws are a prime example. See Eskridge, supra note 104, at 1377 (addressing common law statutes, such as the Sherman Act, where "Congress has declared an important public policy in general, sweeping terms, and has essentially left the courts free to mold the contours of that policy"); Daniel A. Farber \& Brett H. McDonnell, "Is There a Text in This Class?" The Conflict Between Textualism and Antitrust, $14 \mathrm{~J}$. CONTEMP. LEGAL Issues 619, 620 (2005) ("Antitrust cases generally discuss precedent and economic policy. They rarely include more than a passing citation to the statutory text.").

106. Patentability boiled down to the following terse formulation: "[W]hen any person ... shall allege that he ... invented any new and useful art, machine, manufacture or composition of matter, or any new and useful improvement ... not known or used before the application ... a patent may be granted therefor ...." Patent Act of 1793, ch. 11, 1,1 Stat. 318, 318-20.

107. See Craig Allen Nard, Legal Forms and the Common Law of Patents, 90 B.U. L. REv. 51 (2010); see also Carbice Corp. v. Am. Patents Corp., 283 U.S. 27, 33 (1931) ("Infringement, whether direct or contributory, is essentially a tort, and implies invasion of some right of the patentee."); Wallace v. Holmes, 29 F. Cas. 74, 80 (C.C.D. Conn. 1871) (No. 17,100 ) (drawing from common law tort principles to hold that "all are tort-feasors, engaged in a common purpose to infringe the patent, and actually, by their concerted action, producing that result"); $c f$. Peter S. Menell \& David Nimmer, Unwinding Sony, 95 CALIF. L. REV. 941, 996-1005 (2007) (chronicling parallel developments in copyright jurisprudence). 
common law roots, character, and responsibilities, ${ }^{108}$ the most influential patent jurists-including Justice Joseph Story, ${ }^{109}$ Justice Benjamin Robbins Curtis, ${ }^{110}$ and Judge Learned Hand ${ }^{11}$ _-operated in a less formal, common-law-oriented mode. ${ }^{112}$ As a consequence, they did not typically tie their interpretation tightly to statutory text where the text was not illuminating. By drawing upon statutory, constitutional, common sense, and experiential sources and insights, they evolved patent law into a workable, dynamic system. When Congress codified patent law in 1952, it intended to perpetuate that jurisprudential tradition, subject to a few clearly articulated revisions. ${ }^{113}$

The evolution of patent law's nonobviousness requirement illustrates one symbiotic permutation by which patent law has developed from its terse original formulation to today's requirements. The early U.S. patent statutes demanded only that an invention be novel and useful to be patentable; they did

108. See generally Harlan F. Stone, The Common Law in the United States, 50 HARV. L. REv. 4 (1936) (describing the tensions between common law and statutory interpretation at the dawn of the New Deal).

109. See Frank D. Prager, The Influence of Mr. Justice Story on American Patent Law, 5 AM. J. LEGAL HIST. 254 (1961); see also, e.g., Folsom v. Marsh, 9 F. Cas. 342, 344 (C.C.D. Mass. 1841) (No. 4901) (Story, J.) ("Patents and copyrights approach, nearer than any other class of cases belonging to forensic discussions, to what may be called the metaphysics of the law, where the distinctions are, or at least may be, very subtile and refined, and, sometimes, almost evanescent."); Whittemore v. Cutter, 29 F. Cas. 1120, 1121 (C.C.D. Mass. 1813) (No. 17,600) (Story, J.) (inferring that "it could never have been the intention of the legislature to punish a man, who constructed such a machine merely for philosophical experiments, or for the purpose of ascertaining the sufficiency of the machine to produce its described effects").

110. See, e.g., Winans v. Denmead, 56 U.S. (15 How.) 330, 344 (1854) (Curtis, J.) (establishing the doctrine of equivalents). It is perhaps no coincidence that he practiced patent law before his appointment to the bench, see O'Reilly v. Morse, 56 U.S. (15 How.) 62, 63 (1854); Le Roy v. Tatham, 55 U.S. (14 How.) 156, 156 (1853), and that his brother, George Ticknor Curtis, authored the leading patent treatise of the era. See supra note 25.

111. See, e.g., Royal Typewriter Co. v. Remington Rand, Inc., 168 F.2d 691 (2d Cir. 1948) (Hand, J.). Judge Learned Hand's integrated interpretive approach-combining deep understanding of statutes, common law reasoning, and pragmatic insight-established key components of the modern intellectual property system. See, e.g., Nichols v. Universal Pictures Corp., 45 F.2d 119 (2d Cir. 1930) (Hand, J.) (establishing the framework for copyright infringement analysis); Aunt Jemima Mills Co. v. Rigney \& Co., 247 F. 407, 412-13 (2d Cir. 1917) (Hand, J., concurring) (establishing the noncompetitive goods doctrine in trademark law). He was, of course, renowned for his common law jurisprudence. See, e.g., United States v. Carroll Towing Co., 159 F.2d 169 (2d Cir. 1947) (Hand, J.).

112. See Prager, supra note 109, at 254 (observing Justice Story "was uninhibited in interpreting words into and out of [the Patent Act]"). The formative cases amply illustrate the common law tradition. See, e.g., The Incandescent Lamp Patent, 159 U.S. 465 (1895) (enablement); Tilghman v. Proctor, 102 U.S. 707 (1881) (accidental anticipation doctrine); Elizabeth v. Pavement Co., 97 U.S. 126 (1878) (experimental-use exception to statutory bar); Winans, 56 U.S. (15 How.) 330 (doctrine of equivalents); Morse, 56 U.S. (15 How.) 62 (interplay of written description and patentability); Le Roy, 55 U.S. (14 How.) 156 (limits on patentable subject matter); Hotchkiss v. Greenwood, 52 U.S. (11 How.) 248 (1851) (nonobviousness requirement); Whittemore, 29 F. Cas. at 1121 (experimental-use defense).

113. See supra Part I.C. 
not expressly require that a claimed invention meet a separate and distinct requirement for inventiveness or nonobviousness. ${ }^{114}$ Yet the Supreme Court in 1850 read such a limitation into the statute, ${ }^{115}$ and the courts evolved a rich doctrine through a century of jurisprudence. ${ }^{116}$ The source of the requirement-whether constitutional, statutory, jurisprudential, or some combination-remains somewhat murky. ${ }^{117}$ After the Supreme Court appeared to elevate the nonobviousness threshold to "flash of creative genius" nearly a century later, ${ }^{118}$ Congress stepped in and wrote a nonobviousness standard in the statute, but specifically removed the reference to "creative" or "inventive genius." 119 Courts today focus on the statutory text, but they also reference the historical development of nonobviousness doctrine. ${ }^{120}$

The 1952 codification and later enactments reflect several other permutations as well. Where previous statutory provisions sufficed, Congress simply repeated the original statutory text while implicitly carrying over the jurisprudential gloss. This approach largely characterizes the area of patentable subject matter; ${ }^{121}$ it also characterizes the utility requirement, and much of the novelty standard. ${ }^{122}$ In some contexts, Congress expressly codified jurisprudential doctrines $-\delta 102(\mathrm{e})^{123}$ and the indirect liability provisions fit that model. ${ }^{124}$ In

114. See Edmund W. Kitch, Graham v. John Deere Co.: New Standards for Patents, 1966 SUP. CT. REV. 293, 303-04.

115. See Hotchkiss, 52 U.S. (11 How.) at 266-67.

116. See Graham v. John Deere Co., 383 U.S. 1, 11-12 (1966) ("[Hotchkiss] gave birth to 'invention' as a word of legal art signifying patentable inventions. . . . The Hotchkiss formulation, however, lies not in any label, but in its functional approach to questions of patentability.").

117. Compare Great Atl. \& Pac. Tea Co. v. Supermarket Equip. Corp., 340 U.S. 147, 155 (1950) (Douglas, J., concurring) ("The standard of patentability is a constitutional standard ...."), with Graham, 383 U.S. at 15 (upholding the 1952 Patent Act's formulation of the nonobviousness requirement, which abolished the "flash of creative genius" standard).

118. See Great Atl. \& Pac. Tea Co., 340 U.S. at 152 (invalidating a patent on a commercially successful mechanical device as "wanting in any unusual or surprising consequences"); Cuno Eng'g Corp. v. Automatic Devices Corp., 314 U.S. 84, 91 (1941) (describing "the flash of creative genius, not merely the skill of the calling").

119. See H.R. REP. No. 82-1923, at 18 (1952) ("[I]t is immaterial whether [the invention] resulted from long toil and experimentation or from a flash of genius.").

120. See KSR Int'l Co. v. Teleflex Inc., 550 U.S. 398, 406 (2007) ("In Graham . . ., the Court set out a framework for applying the statutory language of $\S 103$, language itself based on the logic of the earlier decision in Hotchkiss . . . and its progeny.").

121. See H.R. REP. No. 82-1923, at 17 ("Section 101 follows the wording of the existing statute as to the subject matter for patents, except that reference to plant patents has been omitted for incorporation in section 301 and the word 'art' has been replaced by 'process', which is defined in section 100.").

122. See id. ("No change is made in [\$102(a)-(c)] other than that due to division into lettered paragraphs. The interpretation by the courts of paragraph (a) as being more restricted than the actual language would suggest (for example, 'known' has been held to mean 'publicly known') is recognized but no change in the language is made at this time.").

123. See id. ("Paragraph (e) is new and enacts the rule of Milburn v. DavisBournonville ...."). 
other contexts, Congress did not codify the jurisprudential doctrines that had emerged-such as the doctrine of equivalents or the experimental use defense-but gave no indication that it sought to abrogate those doctrines. Later courts have continued to apply those doctrines, ${ }^{125}$ notwithstanding the lack of textual hooks.

Thus, in interpreting patent law, courts should determine the provenance of the provision or doctrine in question and then apply the appropriate interpretive lens. In stage one of the analysis, courts should ascertain whether any constitutional provision constrains legislative or judicial power to establish or apply the legal provision or doctrine in question. The principal constitutional constraints concern the "promote . . . Progress," "useful Arts," and "limited Times" limitations on legislative authority to enact patent protection. ${ }^{126}$ Other constitutional provisions - such as the Fifth Amendment, ${ }^{127}$ the Eleventh Amendment, ${ }^{128}$ and possibly the First Amendment ${ }^{129}$ - could also come into play.

Assuming those constitutional limitations do not constrain legislative or judicial power, then courts should, in stage two of the analysis, determine the appropriate interpretive lens. Stage two branches between express Patent Act provisions and nonstatutory judicial doctrines. With regard to express provisions, courts should determine the provenance of legislative text: (a) carryover of statutory text without substantive change; (b) substantive revision or augmentation of statutory text; (c) codification of judicial doctrine without substantive change; (d) codification of judicial doctrine with substantive change; or (e) entirely new provision. Where Congress did not evince an intent to change the prior law (scenarios (a) and (c), or silence with regard to nonstatutory judicial doctrines (i.e., no inconsistent textual provision)), courts should perpetuate the common-law-type jurisprudential tradition. Where Congress changed a preexisting statutory provision (scenario (b)) or added an entirely new statutory provision (scenario (e)), then courts should use modern tools of statutory interpretation. Where Congress codified, but altered, a preexisting jurisprudential

124. See 35 U.S.C. $\S 271$ (b)-(c) (2006); H.R. REP. 82-1923, at 9 (observing that, although there is "no declaration of what constitutes infringement in the present statute," "[t]he doctrine of contributory infringement has been part of our law for about 80 years").

125. See Warner-Jenkinson Co. v. Hilton Davis Chem. Co., 520 U.S. 17, 25-26 (1997) (rejecting petitioner's argument that the doctrine of equivalents failed to survive the Patent Act of 1952, notwithstanding the lack of any textual support for the doctrine); Aro Mfg. Co. v. Convertible Top Replacement Co., 365 U.S. 336, 342 (1961) (holding that the new section defining infringement "left intact the entire body of case law on direct infringement").

126. U.S. ConsT. art. I, $\S 8$, cl. 8.

127. See Adam Mossoff, Patents as Constitutional Private Property: The Historical Protection of Patents Under the Takings Clause, 87 B.U. L. REV. 689, 691 (2007) ("[J]urists once ... held that patents were protected under the Takings Clause.").

128. See Coll. Sav. Bank v. Fla. Prepaid Postsecondary Educ. Expense Bd., 527 U.S. 666 (1999) (holding that the Eleventh Amendment bars federal intellectual property suits against states in federal court).

129. See Dan L. Burk, Patenting Speech, 79 TEX. L. Rev. 99, 160 (2000). 
doctrine (scenario (d)), then courts should integrate modern statutory interpretation with common law jurisprudence to the extent appropriate to effectuate Congress's guidance.

This framework captures Congress's approach in enacting the 1952 Act. The Bilski majority mistakenly treats the 1952 Act largely as though Congress drafted its provisions from scratch. That is how it comes to the interpretive decision to focus on the meaning of "process" by reference to a contemporary dictionary. But as explained previously, ${ }^{130}$ the primary motivation for enacting the 1952 legislation was as part of a more general effort to consolidate and codify patent law for inclusion in the U.S. Code. A secondary motivation was to make a few clearly designated substantive changes to patent law. Rather than codify all of the many jurisprudential embellishments, Congress carried over much of the prior law through acquiescence. Hence, modern courts have a responsibility to perpetuate those doctrinal embellishments as well as the interpretive approach underlying them. There is no indication that Congress intended to freeze those doctrines in place. Congress would certainly have had no basis for anticipating that the Supreme Court would, beginning in the 1990s, gravitate toward strict textualism; ${ }^{131}$ hence, it would undermine fidelity to the legislative schema to interpret the statute through that lens.

So how should the Supreme Court have resolved the Bilski case? The Court should have first confronted whether the Constitution constrains legislative and judicial power to protect nontechnological arts. The historical record strongly indicates that "useful Arts" was understood at the time of the Constitutional Convention to limit patents to technological fields. This is reinforced by the related concern that government not create arbitrary monopolies on the stream of commerce. Justice Stevens's concurrence provides a persuasive explication of these sources. ${ }^{132}$

It is ironic for Justice Stevens and the liberal wing of the Court to be eloquently urging an originalist interpretation of the Constitution while the conservative wing avoids the issue entirely. This is a stark reversal in roles from a recent Second Amendment case. ${ }^{133}$ Original intent is certainly relevant to the inquiry of the appropriate scope of patentable subject matter. And if there is no clear or compelling social, economic, or pragmatic reason for diverging from that understanding, then it makes sense to use the originalist understanding.

There is no reason to believe that "business methods" have become a science or technology fitting the functional patent mold during the course of the past two centuries. Furthermore, the fact that business methods can be implemented on computers does not mean that courts cannot distinguish between ad-

130. See supra Part I.C.

131. See Frickey, supra note 101.

132. See Bilski v. Kappos, 130 S. Ct. 3218, 3239-45 (2010) (Stevens, J., concurring in the judgment).

133. See District of Columbia v. Heller, 128 S. Ct. 2783 (2008). 
vances in computer technology and the business methods that they implement. ${ }^{134}$ Any creation-from business methods to books or movies-can be implemented in a computer environment, but that should not convert the processes used or the machines implementing these processes into independently patentable subject matter unless the advance improves the operation of the machine itself (e.g., improves its processing speed or memory capacity). Merely implementing a process-such as running a business or entertaining an audience-on a machine should not thereby make the process or machine eligible for patent protection. The process must make a technological advance. Merely hedging a risk does not suffice.

Thus, the Court did not need to reach the statutory question. But for completeness, the Court should have grounded its statutory interpretation in a historically forthright explication of the patentable subject matter doctrine: (1) nineteenth-century courts read nontextual limitations into the terse 1793 text based upon a functional, common law approach; (2) the 1952 Act perpetuated that framework in interpreting and applying patentable subject matter limitations; and (3) courts should be attentive to changes in technology that could justify refining those principles.

Had the majority considered these sources, it would have seen that the Patent Act of 1952 provides an independent basis for ruling Bilski's claimed invention ineligible for patent protection. Contrary to the Bilski majority's analysis, Congress employed a special meaning to the term "process" in the 1952 legislation based upon the rich jurisprudence of the prior one hundred years. ${ }^{135}$ That jurisprudence limited "process" or "art" to physical acts that produce a physical or chemical transformation or operate a machine. While courts should be free to examine whether new understandings of technology justify expanding that definition so as to promote progress, the claimed invention in Bilski offers no basis for making such an adjustment to the doctrine.

\section{CONCLUSION}

The Supreme Court's textualist turn has worked a great disservice to the promotion of progress in the useful arts and preserving free enterprise. By replacing the patent system's rich jurisprudential tradition with dictionary definitions, the Bilski decision fundamentally misconstrues the contours of patentable subject matter and undermines the dynamic process that has guided the evolution of patent law since the nation's founding. The patentable subject matter pathology cannot be cured without confronting the roots of the disease: the lack of a forthright, principled framework for delineating the boundaries of patenta-

134. See 1 DELLER, supra note 45 , at 69 (recognizing that "a system of cash-registering and checking for hotels" can be distinguished from "the physical means of conducting the system").

135. See supra Part I.B; see also Cochrane v. Deener, 94 U.S. 780, 788 (1877). 
ble subject matter. The solution lies in recognizing that patentable subject matter cannot evolve to meet the new challenges of the information age without integrating eighteenth-, nineteenth-, and twentieth-century sources of patentable subject matter law into a flexible and evolving body of common law that is sensitive to history, statutory evolution, constitutional constraints, and understanding of modern science and technology. This will be particularly important as courts confront the patentability of DNA compounds, diagnostic tests, and unforeseeable information age innovations. ${ }^{136}$

136. See Allen K. Yu, Within Subject Matter Eligibility-A Disease and a Cure, $84 \mathrm{~S}$. CAL. L. REV. 387 (2011) (exploring the challenges of determining patentability of molecular biology and other information age inventions). 